\title{
Clinical outcomes and molecular genotyping of Staphylococcus aureus isolated from milk samples of dairy primiparous Mediterranean buffaloes (Bubalus bubalis)
}

\author{
J. Guccione, ${ }^{* 1}$ A. Cosandey,† A. Pesce,‡ A. Di Loria,§ M. Pascale,\# D. Piantedosi, ${ }^{*}$ A. Steiner,ll \\ H. U. Graber, $t^{2}$ and P. Ciaramella*2 \\ *Department of Veterinary Medicine and Animal Productions, University of Napoli "Federico II," Via Delpino 1, 80137 Napoli, Italy \\ †Agroscope Liebefeld-Posieux Research Station ALP, 3003 Berne, Switzerland \\ †lstituto Zooprofilattico del Mezzogiorno, Via A. Jervolino 19, 81100 Tuoro, Caserta District, Italy \\ $\S$ Department of Health Science, University of Magna Graecia of Catanzaro, 88100 Catanzaro, Italy \\ \#Veterinary practitioner, Caserta District, 81100 Italy \\ ॥Clinic for Ruminants, Department of Clinical Veterinary Medicine, Vetsuisse-Faculty, University of Berne, 3001 Switzerland
}

\begin{abstract}
Staphylococcus aureus is one of the most important pathogens causing mastitis in dairy cows and in Mediterranean buffaloes. Genotype B (GTB) is contagious in dairy cows and may occur in up to $87 \%$ of cows of a dairy herd. It was the aim of this study to evaluate genotypes present, clinical outcomes, and prevalence of Staph. aureus in milk samples of primiparous Mediterranean dairy buffaloes. Two hundred composite milk samples originating from 40 primiparous buffaloes were collected from May to June 2012, at d 10, 30, 60, 90, and $150 \mathrm{~d}$ in milk (DIM) to perform somatic cell counts and bacteriological cultures. Daily milk yields were recorded. Before parturition until 40 to 50 DIM, all primiparous animals were housed separated from the pluriparous animals. Milking was performed in the same milking parlor, but the primiparous animals were milked first. After 50 DIM, the primiparous were mixed with the pluriparous animals, including the milking procedure. Individual quarter samples were collected from each animal, and aliquots of $1 \mathrm{~mL}$ were mixed and used for molecular identification and genotyping of Staph. aureus. The identification of Staph. aureus was performed verifying the presence of nuc gene by nuc gene PCR. All the nuc-positive isolates were subjected to genotype analysis by means of PCR amplification of the 16S-23S rRNA intergenic spacer region and analyzed by a miniaturized electrophoresis system. Of all 200 composite samples, 41 (20.5\%) were positive for Staph. aureus, and no genotype other than GTB was identified. The prevalence of samples positive for Staph. aureus was $0 \%$ at 10 DIM and increased to a maximum of 22/40 (55\%)
\end{abstract}

Received June 5, 2014.

Accepted September 10, 2014.

${ }^{1}$ Corresponding author: jacopo.guccione@unina.it

${ }^{2}$ These authors contributed equally to the present study. at 90 DIM. During the period of interest, 14 buffaloes tested positive for Staph. aureus once, 6 were positive twice, and 5 were positive 3 times, whereas 15 animals were negative at every sampling. At 90 and 150 DIM, $7(17.5 \%)$ and 3 buffaloes (7.5\%), respectively, showed clinical mastitis (CM), and only 1 (2.5\%) showed CM at both samplings. At 60, 90, and 150 DIM, 1 buffalo was found with subclinical mastitis at each sampling. At 30, 60, 90, and 150 DIM, 2.5 (1/40), 22.5 (9/40), 35 $(14 / 40)$, and $10 \%(4 / 40)$ were considered affected by intramammary infection, respectively. Buffaloes with CM caused by Staph. aureus had statistically significantly higher mean somatic cell count values (6.06 \pm $0.29, \log _{10}$ cells $/ \mathrm{mL} \pm$ standard deviation) and statistically significantly lower mean daily milk yields $(7.15 \pm$ 1.49 , liters/animal per day) than healthy animals (4.69 \pm 0.23 and $13.87 \pm 2.64$, respectively), buffaloes with IMI (4.82 \pm 0.23 and $11.16 \pm 1.80$, respectively), or with subclinical mastitis $(5.47 \pm 0.10$ and $10.33 \pm 0.68$, respectively). Based on our knowledge, this is the first time that Staph. aureus GTB has been identified in milk samples of dairy Mediterranean buffaloes.

Key words: Staphylococcus aureus, genotype B, mastitis, Mediterranean buffalo, udder health

\section{INTRODUCTION}

Staphylococcus aureus is one of the most important pathogens, causing chronic, clinical, and mainly subclinical mastitis in dairy cows all over the world (Sears and McCarthy, 2003). Considering the negative effect of Staph. aureus on milk quality and yield, it is recognized as a cause of great economic loss for the dairy industry (Barkema et al., 2006, 2009; Keefe, 2012). It has been demonstrated that Staph. aureus isolated from mastitis milk of dairy cows represents a genetically heterogeneous group of bacteria (Fournier et al., 2008). By means of PCR amplification of the 16S-23S rRNA 
intergenic spacer region (ribosomal spacer-PCR), an accurate and repeatable method to subtype Staph. aureus, a total of 17 genotypes were detected in 101 epidemiologically independent isolates (Graber et al., 2009). Genotype B (GTB) and C were the most common $(80.2 \%)$, whereas the other 15 genotypes occurred rarely. It was further demonstrated that the genotypes were highly associated with their virulence gene pattern (Fournier et al., 2008; Graber et al., 2009). Actually, more than 20 different genotypes of Staph. aureus with different virulence and pathogenicity factors were identified in mastitis milk of dairy cows, originating from a variety of European countries (Anderson et al., 2012; Cosandey and Graber, 2013; Lundberg et al., 2014). Some Staph. aureus strains were recognized as contagious pathogens because they can spread from infected to noninfected cows at milking (Bartlett and Miller, 1993; Fox and Gay, 1993; Sears and McCarthy, 2003). Genotype B was related to contagiousness and increased pathogenicity, causing herd problems with a within-herd prevalence of up to $87 \%$, and often 2 or more quarters were affected per cow. By contrast, other genotypes were found in samples of single cows (ranging from 4 to $33.3 \%$ ) with only 1 quarter per cow infected (Michel et al., 2011).

As in dairy cows, bacterial mastitis is 1 of the most costly diseases also in dairy Mediterranean buffaloes (Galiero, 2002; Fagiolo and Lai, 2007), mainly in primiparous animals, where the highest incidence of mastitis was reported during the first 2 mo of milking (Dhakal et al., 2008). In dairy buffaloes, Staph. aureus is the most problematic and significant contagious pathogen exhibiting strains particularly resistant to antibiotics (Fagiolo and Lai, 2007; Guccione et al., 2014). Staphylococcus aureus typically colonizes the injured skin. Damage of the teat end and faulty milking encourages migration of bacteria into the udder, and Staph. aureus may remain viable in affected buffalo farms for an extended period of time (Fagiolo and Lai, 2007). According to Trinidad et al. (1990), even mild IMI due to Staph. aureus can cause damage to the developing secretory tissue that can lead to decreased milk yield followed by increased SCC. Somatic cell count is usually used as indicator of inflammation to diagnose mastitis (Dhakal et al., 1992; Singh and Ludri, 2001; Moroni et al., 2006), and, according to Cerón-Muñoz et al. (2002), elevated SCC values were related to reduced lactose concentration and milk yield. According to several studies in buffaloes, quarters producing milk with an SCC below the threshold of $200 \times 10^{3}$ cells $/ \mathrm{mL}$ and associated with negative bacteriological cultures (BC) are considered healthy; quarters with analogous SCC values and positive BC caused by udder-specific pathogens are considered affected by IMI. Further- more, buffaloes producing milk with an SCC upon the threshold of $200 \times 10^{3}$ and positive BC are defined as suffering from subclinical mastitis (SM), whereas in cases of clinical mastitis (CM), obvious signs of disease involving the appearance of the milk or udder are evident (Moroni et al., 2006; Tripaldi et al., 2010). For commercial purposes, the European Union Directives (46/92 and 71/94) set an upper limit of $400 \times 10^{3}$ cells/ $\mathrm{mL}$ for the SCC of buffalo milk to be used for products made from raw milk intended for human consumption (Moroni et al., 2006).

In both buffaloes and cattle, clinical suspicion for the presence of mastitis due to Staph. aureus is based on a combination of the following findings: visible changes of milk, atrophy or presence of indurations of the affected quarter (Radostits et al., 2007), presence of certain risk factors such as teat lesions or callused teats (Sieber and Farnsworth, 1984; Zadoks et al., 2001), positive result of the California Mastitis Test (CMT), and elevation of the SCC (Schukken et al., 2003). Confirmation or exclusion is based on BC of one or, preferably, several consecutive milk samples (Sears and McCarthy, 2003). The nuc gene is highly specific for Staph. aureus (Brakstad et al., 1992; Graber et al., 2007) and may, therefore, be used for definitive identification of suspicious colonies (Syring et al., 2012).

Although Staph. aureus is considered one of the most important udder-specific pathogens in Mediterranean buffaloes (Fagiolo and Lai, 2007), published studies exploring the role of Staph. aureus as udder pathogen in first-lactation dairy buffaloes are rare. Therefore, the aims of the present study were to (1) evaluate the clinical outcomes and prevalence of Staph. aureus IMI in the primiparous animals of a Mediterranean buffalo herd, (2) identify the genotypes present, (3) describe the dynamics of Staph. aureus IMI over repeated samplings within the first 150 DIM, (4) follow the prevalence of udder-specific bacteria other than Staph. aureus, and (5) elucidate the potential pathway of infection of primiparous animals.

\section{MATERIALS AND METHODS}

\section{Study Design, Animals, and Farm Management}

For our study, 40 primiparous and 20 pluriparous Mediterranean buffaloes were used. They were all reared in a breeding farm of 600 dairy buffaloes, located in the Caserta district in southern Italy, and were chosen by convenience sampling between May and June 2012 . Before parturition until 40 to 50 DIM, all primiparous animals were housed separated from the pluriparous animals. Milking was performed in the same milking parlor, but the primiparous animals were milked first. 
After 50 DIM, the primiparous were mixed with the pluriparous animals, including the milking procedure.

\section{Milk Samples}

Milk samples were collected aseptically in sterile test tubes immediately before regular evening milking, as described by National Mastitis Council (2004) for dairy cows. At 10, 30, 60, 90, and 150 DIM, 2 samples from each quarter of the 40 primiparous were collected. Milk samples were created by mixing equal amounts of milk from all 4 quarters into a sterile test tube (BD Vacutainer, Oxford, UK). The first sample $(4 \mathrm{~mL})$ was immediately frozen $\left(-20^{\circ} \mathrm{C}\right)$ until further processing for molecular genotyping of Staph. aureus, whereas the second sample $(50 \mathrm{~mL})$ was used to perform BC and determine the SCC. From the 20 pluriparous animals, 1 composite milk sample of $10 \mathrm{~mL}$ was collected once aseptically and frozen at $-20^{\circ} \mathrm{C}$ for $\mathrm{BC}$ and genotyping of Staph. aureus later.

\section{Clinical Examination, CMT, and Electrical Conductivity}

On the days of sampling, each individual primiparous buffalo enrolled was individually submitted to a complete clinical examination before evening milking, with a particular focus on udder health status. Local and systemic signs and changes in milk appearance were recorded during each sampling. Buffaloes showing abnormal macroscopic appearance of the milk were also submitted to complete hemato-biochemical analysis. A complete ultrasonographic examination of the 4 teats and mammary glands was also performed in buffaloes with SM or CM, using a $12-\mathrm{MHz}$ linear probe (General Electrics, Logiq E, Milano, Italy). The teats were dipped in warm water to improve image quality as described for the cow by Sendag and Dinc (1999). California Mastitis Test was routinely performed from each composite milk sample, with values $\geq 1$ interpreted as positive. Electrical conductivity (EC) and daily milk yields were recorded using automatic dedicated software (Afifarm, Afimilk, Kibbutz Afikim, Israel). Based on this classification, the animals enrolled were defined as healthy $(\mathbf{H})$ or affected by IMI, SM, or CM, considering the presence of clinical signs, the SCC values, and the microbiological status (Moroni et al., 2006; Fagiolo and Lai, 2007; Tripaldi et al., 2010).

\section{SCC and Bacteriological Milk Cultures}

The composite milk samples were placed in a cool box $\left(4^{\circ} \mathrm{C}\right)$ and brought to the reference laboratory within $1 \mathrm{~h}$ of collection, where they were submitted to SCC analysis and $\mathrm{BC}$ within $2 \mathrm{~h}$ of collection. Somatic cell count was determined using an automatic and dedicated analyzer, approved for buffalo milk (Fossomatic 5000, Foss Electric, Hillerød, Denmark). The BC was performed according to guidelines of the National Mastitis Council (1999). Briefly, $10 \mu \mathrm{L}$ of each milk sample was streaked on one quarter of a blood-agar plate (Merck KGaA, Darmstadt, Germany), incubated at $37^{\circ} \mathrm{C}$ for up to $48 \mathrm{~h}$, and examined after 24 and $48 \mathrm{~h}$ of incubation. The identification of Staph. aureus and other mastitis pathogens was according to the guidelines of the National Mastitis Council (1999). Bacterial colonies were tentatively identified on gross morphology, and the number and types of colonies were recorded. According to Kreiger et al. (2007), when 3 or more dissimilar colony types were isolated on the plate, the sample was considered contaminated. Appropriate tests were performed with the colonies isolated, where necessary, to identify the pathogens. These included Gram staining, catalase testing to differentiate between streptococci and staphylococci, and tube coagulase testing using rabbit plasma to differentiate between coagulase-positive staphylococci and CNS. A final identification of microorganisms was performed using the colorimetric automated identification system (Vitek 2 XL 120; bioMerieux Inc., Hazelwood, MO), according to the manufacturer's instructions. Enterobacteriaceae were grown on MacConkey agar (Oxoid, Basingstoke, UK) and were also identified using the same automated system. Isolates identified with confidence levels greater than 0.90 were considered identified mastitis pathogens at species level. Otherwise, they were identified at genus level.

\section{Identification of Staph. aureus and Molecular Genotyping}

Samples for PCR analysis were thawed and $10 \mu \mathrm{L}$ of milk was streaked both on chrom-agar and on bloodagar plates (bioMérieux Suisse, Geneva, Switzerland) and incubated at $37^{\circ} \mathrm{C}$ overnight to obtain single colonies typical of Staph. aureus and to verify the rate of contamination, respectively. Five colonies of each chrom-agar plate were subcultured on blood-agar plates obtaining the growth of pure strains. The final identification of the Staph. aureus was performed verifying the presence of nuc gene, coding for the thermonuclease. For this reason, the colonies were resuspended in 100 $\mu \mathrm{L}$ of TEL buffer $(10 \mathrm{~m} M$ Tris/HCl, $10 \mathrm{~m} M$ EDTA; $\mathrm{pH}$ $=8.5$ ), incubated at $95^{\circ} \mathrm{C}$ for $10 \mathrm{~min}$, and immediately placed on ice. The lysates were then diluted 1:100 in $\mathrm{H}_{2} \mathrm{O}$ and served as templates for the different types of PCR. The PCR for the nuc gene was performed according to (Syring et al., 2012). Isolates lacking this gene 
were excluded from the present study. All the positive isolates were then subjected to genotype analysis according to Fournier et al. (2008).

This method is based on PCR amplification of the 16S-23S rRNA intergenic spacer region. Each reaction contained (total volume $=25 \mu \mathrm{L}$ ) $1 \times$ HotStarTaq Master Mix (Qiagen AG, Hombrechtikon, Switzerland), 800 $\mathrm{n} M$ of each primer (G1 and L1 primer), and $7 \mu \mathrm{L}$ of diluted lysate. The PCR profile was $95^{\circ} \mathrm{C}$ for $15 \mathrm{~min}$, followed by 27 cycles at $94^{\circ} \mathrm{C}$ for 1 min, followed by a 2 -min ramp, and annealing at $55^{\circ} \mathrm{C}$ for $7 \mathrm{~min}$. After a further 2-min ramp, extension was done at $72^{\circ} \mathrm{C}$ for 2 min. The PCR was terminated by a final extension at $72^{\circ} \mathrm{C}$ for $10 \mathrm{~min}$ followed by cooling down to $4^{\circ} \mathrm{C}$. Negative and positive controls were included in every run. For the negative control, sterile water was added instead of nucleic acids. For positive control, we used bovine strains positive for Staph. aureus GTB.

The PCR products of the 16S-23S rRNA intergenic spacer region were analyzed by the miniaturized electrophoresis system DNA 7500 LabChip (Agilent Technologies, Santa Clara, CA). The electropherograms were monitored online on a personal computer, evaluated and translated into a pseudo-gel by Agilent Technologies software. For interpretation of the 16S-23S rRNA intergenic spacer region results, 2 patterns (genotypes) were considered different if 2 and more peaks of the electropherogram differed in size. To identify the genotypes, a recently developed in-house computer program was applied (Syring et al., 2012).

\section{Statistical Analysis}

Different animal health status, SCC, and milk yields were analyzed by standard descriptive statistics, and normality was assessed using histograms, normal probability plots and Shapiro Wilk tests. Data were expressed as absolute numbers, percentage, or mean \pm SD. Somatic cell counts were expressed as $\log _{10}$ (cells/ $\mathrm{mL}$ ). Untransformed and log-transformed variables were described using box plots and compared using parametric tests (Student's $t$-test). Probabilities $<0.05$ were considered significant. All the statistical data were analyzed using dedicated software (Version 17.0, SPSS, Chicago, IL).

\section{RESULTS}

\section{Clinical and Ultrasonographic Findings}

Overall appearance of depression, udder swelling and pain, off-color and watery appearance of milk, and presence of flakes, clots, or pus were detected during the clinical examination in CM quarters. A slight neutro- philia (data not shown) and obvious ultrasonographic abnormalities were always found in all the examined mastitic buffaloes. Ultrasonographically, partial teat canal occlusions due to fibrin deposits and irregular outlines of the teat cisterns were observed in buffaloes affected by CM.

\section{CMT, SCC, and EC}

During the current study, the CMT was always positive in animals with CM and SM due to Staph. aureus; it was negative in $62.2 \%$ and positive in $37.8 \%$ of animals with IMI, whereas it was negative in $82.4 \%$ and positive in $17.6 \%$ of $\mathrm{H}$ buffaloes. The SCC values ranged from 4.28 to $5.24 \log _{10}$ cells $/ \mathrm{mL}$ (mean $=4.69$ \pm 0.23 cells $/ \mathrm{mL}$ ) in $\mathrm{H}$ buffaloes and from 4.38 to 6.53 $\log _{10}$ cells $/ \mathrm{mL}($ mean $=5.10 \pm 0.55$ cells $/ \mathrm{mL})$ in buffaloes that tested positive for Staph. aureus. Statistically significant differences were found between the 2 groups $(P<0.001)$. The EC values ranged from 6.90 to 10.40 $\mathrm{mS} / \mathrm{cm}($ mean $=8.29 \pm 0.61 \mathrm{mS} / \mathrm{cm})$ in $\mathrm{H}$ buffaloes and from 7.80 to $14.00 \mathrm{mS} / \mathrm{cm}$ (mean $=8.69 \pm 1.30$ $\mathrm{mS} / \mathrm{cm}$ ) in those positive for Staph. aureus.

\section{$B C$ and Staph. aureus Genotyping}

The prevalence of the bacteria isolated during the present study is indicated in Table 1 . Of all samples, $41 / 200(20.5 \%)$ primiparous and 12/20 (60\%) pluriparous animals were positive for Staph. aureus. Without any exception, all Staph. aureus strains isolated were identified as GTB. The prevalence of Staph. aureus was $0 \%(0 / 40)$ at 10 DIM and increased to $2.5(1 / 40), 25$ $(10 / 40), 55(22 / 40)$, and $20 \%(8 / 40)$ at $30,60,90$, and 150 DIM, respectively (Table 1). During the period of interest, 14 buffaloes tested positive for Staph. aureus once, 6 were positive twice, and 5 were positive 3 times, whereas 15 animals were always negative for Staph. aureus. No co-infection between Staph. aureus and other udder-specific pathogens was recorded at 30 and 150 DIM; $1 / 10$ (10\%) of samples showed a co-infection (Streptococcus uberis) at 60 DIM, and 4/22 (18.2\%) samples at 90 DIM [Staphylococcus spp. (1); Streptococcus dysgalactiae (1); other bacteria (2)]. All of these co-infected samples $(5 / 32)$ became mono-infected by Staph. aureus in the consecutive sampling. Regarding pluriparous buffaloes, no co-infection between Staph. aureus and other udder specific bacteria were detected.

Of all samples of primiparous buffaloes, 79/200 $(39.5 \%)$ were positive for other udder-specific bacteria except Staph. aureus. The prevalence of these positive samples increased from $8 / 40(20 \%)$ at 10 DIM to $28 / 40$ $(70 \%)$ at 30 DIM and then steadily decreased to $25 / 40$ $(62.5 \%)$ at 60 DIM to $15 / 40(37.5 \%)$ at 90 DIM and 
Table 1. Prevalence (\%; no. in parentheses) of udder-specific pathogens isolated from 4 quarter composite milk samples of 40 primiparous buffaloes at 10, 30,60,90, and 150 DIM

\begin{tabular}{lccccc}
\hline & \multicolumn{5}{c}{ DIM } \\
\cline { 2 - 6 } Bacteria & 10 & 30 & 60 & 90 & 150 \\
\hline Staphylococcus aureus & 0 & $2.5(1)$ & $25(10)$ & $55(22)$ & $20(8)$ \\
Staphylococci & $7.5(3)$ & $22.5(9)$ & $25(10)$ & $22.5(9)$ & $2.5(1)$ \\
Streptococcus uberis & - & $7.5(3)$ & $10(4)$ & - & - \\
Streptococcus dysgalactiae & $2.5(1)$ & $15(6)$ & $-\overline{-}$ & $2.5(1)$ & - \\
Escherichia coli & $5(2)$ & $2.5(1)$ & $10(4)$ & $5(2)$ & - \\
Other bacteria & $5(2)$ & $22.5(9)$ & $17.5(7)$ & $7.5(3)$ & $5(2)$ \\
\hline
\end{tabular}

$3 / 40(7.5 \%)$ at 150 DIM. Staphylococcus spp. and other bacteria were identified at every sampling date (Table 1). The number of negative samples recorded during the whole study was $80 / 200(40 \%)$.

\section{Classification of Udder Health Status}

Clinical mastitis due to Staph. aureus was present in $17.5 \%(7 / 40)$ of buffaloes at 90 DIM, and $7.5 \%(3 / 40)$ at 150 DIM; 1 buffalo showed CM both at 90 and 150 DIM. One buffalo showed SM at 60, 90, and 150 DIM. In all CM and SM due to Staph. aureus, no co-infections with other udder-specific pathogens were found. Intramammary infection was diagnosed in $2.5(1 / 40)$, 25 (10/40), $35(14 / 40)$, and $10 \%(4 / 40)$ of buffaloes at $30,60,90$, and 150 DIM, respectively. No IMI was diagnosed at 10 DIM.

\section{Association Between SCC and Udder Health Status}

The mean values of SCC detected in buffaloes affected by CM, SM, IMI due to Staph. aureus, or H were $6.06 \pm 0.29,5.47 \pm 0.10,4.82 \pm 0.23$, and $4.69 \pm$ $0.23 \log _{10}$ cells $/ \mathrm{mL}( \pm \mathrm{SD})$, respectively. Statistically significant differences were found between mean values of SCC in CM and SM $(P=0.0002)$, between $\mathrm{CM}$ or SM and IMI $(P<0.0001)$, and between $\mathrm{CM}$ or SM and $\mathrm{H}$ buffaloes $(P<0.001 ;$ Figure 1$)$.

\section{Association Between EC and Udder Health Status}

Regarding the EC, the mean values recorded in animals affected by CM, SM, IMI due to $S$. aureus, or $\mathrm{H}$ were $10.49 \pm 1.94,8.37 \pm 0.50,8.21 \pm 0.28$, and $8.29 \pm$ $0.61 \mathrm{mS} / \mathrm{cm}$, respectively. Statistically significant differences of EC were observed between buffaloes with $\mathrm{CM}$ as compared with those with SM, IMI, or H $(P<0.01)$.

\section{Association Between Udder Health Status and Milk Yield}

Buffaloes with CM caused by Staph. aureus had significantly lower mean daily milk yields $(7.15 \pm 1.49$,
$\mathrm{L}$ /animal per day) as compared with $\mathrm{H}$ animals (13.87 $\pm 2.64 \mathrm{~L}$ /animal per day; $P<0.0001$ ), buffaloes with IMI $(11.16 \pm 1.80 \mathrm{~L} /$ animal per day; $P<0.0001)$, and those with SM $(10.33 \pm 0.68 \mathrm{~L} /$ animal per day; $P=$ 0.001; Figure 2).

\section{DISCUSSION}

The current study evaluated the clinical outcomes and prevalence of Staph. aureus in milk samples of dairy primiparous Mediterranean buffaloes, simultaneously performing molecular genotyping of the isolated strains. The importance of Staph. aureus as a contagious pathogen has been widely recognized both in dairy cows and buffaloes, but to our knowledge no previous studies have investigated its role in buffalo herds and its genetic characteristics.

The molecular analysis performed in the present study revealed that GTB was the only Staph. aureus strain

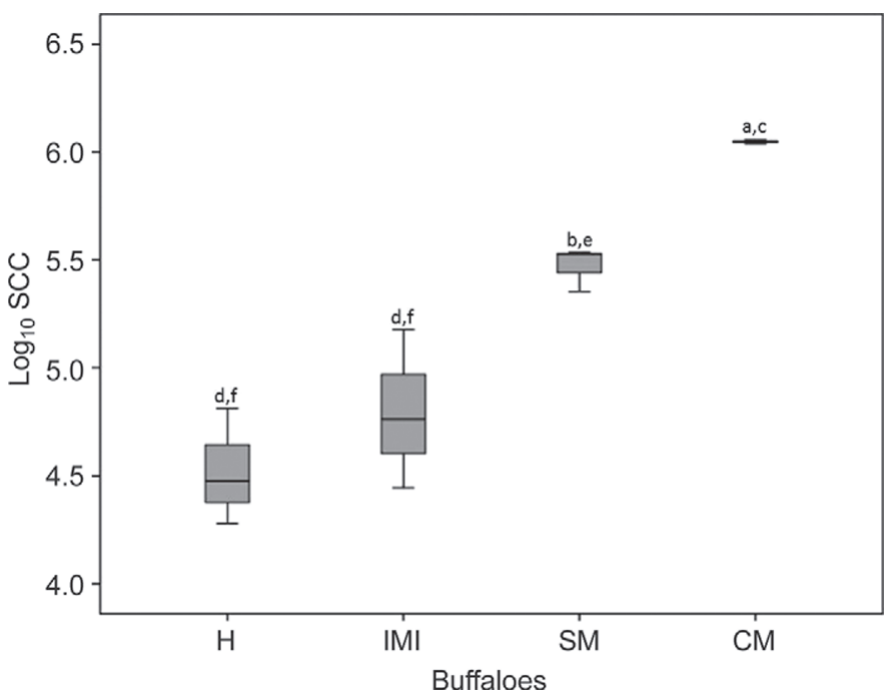

Figure 1. Mean $\log _{10}$ SCC values of milk samples in 40 primiparous buffaloes with 4 different udder health statuses: $\mathrm{H}=$ healthy; IMI $=$ intramammary infection; $\mathrm{SM}=$ subclinical mastitis; $\mathrm{CM}=$ clinical mastitis. Statistically significant differences were found between animals with different udder health statuses. a,b: $P<0.001$, c,d: $P<$ $0.0001 ;$ e,f: $P<0.001$. 


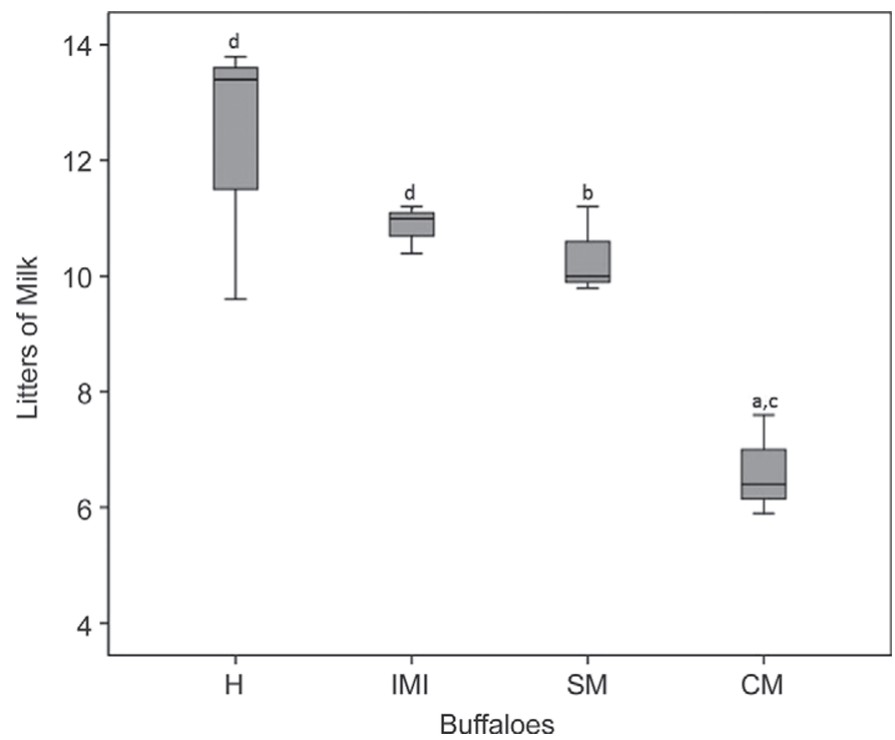

Figure 2. Mean milk yields (L) in 40 primiparous buffaloes with 4 different udder health statuses: $\mathrm{H}=$ healthy; $\mathrm{IMI}=$ intramammary infection; $\mathrm{SM}=$ subclinical mastitis; $\mathrm{CM}=$ clinical mastitis. Statistically significant differences were found between animals with different udder health statuses. a,b: $P=0.001 ; \mathrm{c}, \mathrm{d}: P<0.0001$.

isolated from samples collected both in primiparous and pluriparous buffaloes; analogous studies performed in cows confirmed the high prevalence of GTB-positive samples, showing similar within-herd prevalence (up to 96.1\%; Graber et al., 2009). To our knowledge, our report is the first in which isolation of Staph. aureus GTB from milk samples of dairy primiparous Mediterranean buffaloes was described. Its contagiousness and ability to produce within-herd problems, as well as its virulence due to its gene patterns (enterotoxin genes $\mathrm{A}$ and $\mathrm{D}$ and polymorphic leucotoxin $\mathrm{E}$ gene), were widely described not only in Swiss dairy herds (Fournier et al., 2008; Syring et al., 2012) but also in dairy cows of several European countries (Cosandey and Graber, 2013).

Staphylococcus aureus is one of the most important and best-studied pathogens causing mastitis in dairy cows (Schällibaum, 1999; Zecconi et al., 2005). According to our results, the prevalence of animals with udder health problems (buffaloes affected by IMI, SM, and $\mathrm{CM}$ ) caused by the bacterium (up to $55 \%$; Table 1) as well as the incidence of positive samples for Staph. aureus collected during the whole sampling period (20.4\%) were lower than those described for cows (Michel et al., 2011). Nevertheless, considering the prevalence of CM, $\mathrm{SM}$, and IMI due to the bacterium, as well as its relationship with other udder-specific pathogens isolated in the present study (Table 1), Staph. aureus confirmed its pathogenicity in Mediterranean buffaloes and it can be considered one of the most important pathogens causing within-herd problems in this dairy species.
Staphylococcus aureus is globally recognized for its relevant economic loss for farmers and the dairy industry due to its negative influence on milk yield (Sears and McCarthy, 2003; Seegers et al., 2003). Once established in the udder, Staph. aureus can persist through the precalving period and into the first lactation (Halasa et al., 2007; Hogeveen et al., 2011). According to Trinidad et al. (1990), even mild IMI can lead to decreased milk production followed by increased SCC because of damage to the developing secretory tissue. Secretory tissue is replaced by connective tissue having a deleterious effect on future milk yield (Kreiger et al., 2007). Additional economic losses in dairy cows are also attributed to a compromise of the milk quality due to increased SCC levels (Michel et al., 2011). In the present study, milk production was observed to progressively decline from $\mathrm{H}$ to IMI, SM, and CM (Figure 2). The difference was statistically significant between $\mathrm{H}$ and $\mathrm{CM}$ buffalo $(P$ $<0.0001)$. The results of the current study showed that IMI caused by Staph. aureus GTB in Mediterranean buffalo is associated with significant losses in milk and mozzarella cheese production. This is supported by the results of a recent study performed in Mediterranean buffaloes in which IMI due to udder-specific pathogens led to a SCC above the threshold of $200 \times 10^{3}$ cells $/ \mathrm{mL}$, which is associated both with significantly decreased milk yields and poor milk quality due to changes in its composition and coagulating properties (Tripaldi et al., 2010).

Regarding the mean SCC values observed in buffaloes, IMI due to Staph. aureus mono-infection revealed lower SCC mean values in Mediterranean buffaloes $\left(4.82 \pm 0.23 \log _{10}\right.$ cells $\left./ \mathrm{mL}\right)$ as compared with those detected for cows $\left(5.97 \pm 0.49 \log _{10}\right.$ cells/mL; Graber et al., 2009). Interactions among infection, inflammatory processes, and immune responses in individual udder quarters are still controversially discussed in dairy cows (Schwarz et al., 2011), whereas in dairy buffalo no complete studies are present to explain the relationship. Different leukocyte behavior during the initial phase of the inflammation and stronger pressure from udder pathogenic microorganisms of the environment or stressful events (i.e., kicking during premilking preparation of the udder or during taking the quarter foremilk samples) might have triggered the elevation of the SCC and may explain the difference observed between the 2 species.

Regarding the epidemiological properties of Staph. aureus, the prevalence of IMI at several DIM ranged between 2.5 (1) and 35\% (14), with peaks of infections detected between 60 and 90 DIM; CM and SM were recorded between 60 and 150 DIM. The higher prevalence of IMI due to Staph. aureus GTB observed could contribute to a significant increase of clinically evident 
udder disorders between $90(17.5 \%)$ and 150 (7.5\%) DIM. These results confirm that Staph. aureus GTB is not only contagious, but it is often associated with a clear pathological state. Indeed, abnormal SCC values were recorded in animals affected by SM $(5.47 \pm 0.10$ $\log _{10}$ cells $\left./ \mathrm{mL}\right)$ and $\mathrm{CM}\left(6.06 \pm 0.29 \log _{10}\right.$ cells $/ \mathrm{mL}$; Figure 1); moderate swelling and visible clots (chunks) in the milk, especially in forestripping, represented additional macroscopic evidence associated with a pathological state caused by the bacterium.

According to the current study, the prevalence of other bacteria than Staph. aureus strongly declined in the primiparous animals (Table 1 ) when Staph. aureus GTB appeared. A similar phenomenon was observed in herds of dairy cows with IMI due to GTB (Michel et al., 2011). Indeed, cow and quarter prevalence of CNS and streptococci were considerably and significantly lower in herds with GTB IMI than in herds characterized by IMI due to other Staph. aureus genotypes (genotype C or the remaining genotypes, GTOG). These results suggest that GTB, as a contagious pathogen, protects the mammary gland from infections due to other mastitis pathogens.

No IMI due to Staph. aureus was detected at 10 DIM, whereas a higher prevalence of infection and, consequently, SM and CM were observed between 60 and 150 DIM. These effects may have been caused by mixing the primiparous with the pluriparous animals in the herds, as initiated by the farmer between 40 and 50 DIM. We hypothesized a reservoir role of Staph. aureus GTB for the pluriparous animals. The supplementary analysis of 20 pluriparous buffaloes supported this hypothesis, revealing positive results for Staph. aureus in $60 \%$ of the samples and the presence of the GTB as the only single strain detected in the herd.

Considering the findings of our study and the epidemiological properties of GTB in Mediterranean buffaloes, the following management strategies might be considered. Similar to dairy herds, primiparous and all pluriparous buffaloes that test negative ought to be milked first and those that test positive milked last or with a separate milking unit to avoid further transmission within the herd (Voelk et al., 2014). Additional management strategies might be beneficial, including (1) treating or culling of affected animals, (2) initiating biosecurity measures and testing of buffaloes originating from other herds (Berchtold et al., 2014; Voelk et al., 2014), and (3) implementing and maintaining hygienic milking practices, such as wearing gloves, forestripping, teat cleaning, and postmilking teat disinfection (Barkema et al., 2009; Dufour and Dohoo, 2013). Complete sanitation of the herd might be very costly and time consuming, lasting for up to $1 \mathrm{yr}$, as reported in dairy cattle herds (Kirchhofer et al., 2007).

\section{CONCLUSIONS}

The findings of the current study demonstrate for the first time the presence of Staph. aureus GTB in dairy Mediterranean buffaloes, and GTB can be considered one of the most important bacteria causing IMI, SM, and $\mathrm{CM}$ in this species. The clinical outcomes, the high within-herd prevalence and the negative effect on milk quality and milk yield confirmed that this pathogen is responsible for contagious mastitis and great economic losses in the dairy buffalo industry. Strategies of prevention and control of udder health problems due to Staph. aureus GTB are proposed in this study. However, more complete studies about the effectiveness of the proposed biosecurity measures should be performed both in primiparous and pluriparous buffalo herds to improve scientific knowledge focused on dairy buffalo.

\section{REFERENCES}

Anderson, K. L., R. Lyman, K. Moury, D. Ray, D. W. Watson, and M. T. Correa. 2012. Molecular epidemiology of Staphylococcus aureus mastitis in dairy heifers. J. Dairy Sci. 95:4921-4930.

Barkema, H. W., M. J. Green, A. J. Bradley, and R. N. Zadoks. 2009. Invited review: The role of contagious disease in udder health. J. Dairy Sci. 92:4717-4729.

Barkema, H. W., Y. H. Schukken, and R. N. Zadoks. 2006. Invited review: The role of cow, pathogen, and treatment regimen in the therapeutic success of bovine Staphylococcus aureus mastitis. J. Dairy Sci. 89:1877-1895.

Bartlett, P. C., and G. Y. Miller. 1993. Managerial risk factors for intramammary coagulase-positive staphylococci in Ohio dairy herds. Prev. Vet. Med. 17:33-40.

Berchtold, B., M. Bodmer, B. H. Van den Borne, M. Reist, H. U. Graber, A. Steiner, B. Boss, and F. Wohlfender. 2014. Genotypespecific risk factors for Staphylococcus aureus in Swiss dairy herds with an elevated yield-corrected herd somatic cell count. J. Dairy Sci. 97:4886-4896.

Brakstad, O. G., K. Aasbakk, and J. A. Maeland. 1992. Detection of Staphylococcus aureus by polymerase chain reaction amplification of the nuc gene. J. Clin. Microbiol. 30:1654-1660.

Cerón-Muñoz, M., H. Tonhati, J. Duarte, J. Oliveira, M. Munoz-Berrocal, and H. Jurado-Gomez. 2002. Factors affecting somatic cell counts and their relations with milk and milk constituent yield in buffaloes. J. Dairy Sci. 85:2885-2889.

Cosandey, A., and H.U. Graber. 2013. Subtyping of European Staphylococcus aureus strains isolated from cow milk. Page 137 in Buiatrissima Congress, Bern, Switzerland. Vetsuisse-Fakultät, Bern, Switzerland.

Dhakal, I. P., M. O. Kapur, and A. Sharma. 1992. Significance of differential somatic cell counts in milk for the diagnosis of subclinical mastitis in buffaloes using foremilk and stripping milk. Indian J. Anim. Health 31:39-43.

Dhakal, I. P., M. Neupane, and H. Nagahata. 2008. Evaluation of direct and indirect measures of quarter milk from crossbred buffaloes. Anim. Sci. J. 79:628-633.

Dufour, S., and I. R. Dohoo. 2013. Short communication: Relationship between herd intramammary infection incidence and elimination rate during the dry period. J. Dairy Sci. 96:1672-1676.

Fagiolo, A., and O. Lai. 2007. Mastitis in buffalo. Ital. J. Anim. Sci. 6:200-206.

Fournier, C., P. Kuhnert, J. Frey, R. Miserez, M. Kirchhofer, T. Kaufmann, A. Steiner, and H. U. Graber. 2008. Bovine Staphylococcus aureus: Association of virulence genes, genotypes and clinical outcome. Res. Vet. Sci. 85:439-448. 
Fox, L. K., and J. M. Gay. 1993. Contagious mastitis. Vet. Clin. North Am. Food Anim. Pract. 9:475-487.

Galiero, G. 2002. The control of environmental mastitis. Bubalus bubalis I:26-28.

Graber, H. U., M. G. Casey, J. Naskova, A. Steiner, and W. Schaeren. 2007. Development of a highly sensitive and specific assay to detect Staphylococcus aureus in bovine mastitic milk. J. Dairy Sci. 90:4661-4669.

Graber, H. U., J. Naskova, E. Studer, T. Kaufmann, M. Kirchhofer, M. Brechbuhl, W. Schaeren, A. Steiner, and C. Fournier. 2009. Mastitis-related subtypes of bovine Staphylococcus aureus are characterized by different clinical properties. J. Dairy Sci. 92:1442-1451.

Guccione, J., A. Pesce, M. Pascale, N. Tommasini, F. Garofalo, A. Di Loria, L. Cortese, C. Salzano, and P. Ciaramella. 2014. Short communication: Effects of systemic treatment with penethamate hydriodide on udder health and milk yields in dry primiparous Mediterranean buffaloes (Bubalus bubalis). J. Dairy Sci. 97:2219-2225.

Halasa, T., K. Huijps, O. Osteras, and H. Hogeveen. 2007. Economic effects of bovine mastitis and mastitis management. A review . Vet. Q. 29:18-31.

Hogeveen, H., K. Huijps, and T. J. G. M. Lam. 2011. Economic aspects of mastitis: New developments. N. Z. Vet. J. 59:16-23.

Keefe, G. 2012. Update on control of Staphylococcus aureus and Streptococcus agalactiae for management of mastitis. Vet. Clin. North Am. Food Anim. Pract. 28:203-216.

Kirchhofer, M., L. Tavel, D. Strabel, C. Fournier, A. Steiner, H. U. Graber, and T. Kaufmann. 2007. Herd problem: Udder health. Retrospective study of farms with udder health problems assessed by the Swiss Bovine Health Service (BHS) from 1999 to 2004. Dtsch. Tierarztl. Wochenschr. 114:338-344.

Kreiger, M., G. M. Friton, J. Hofer, K. Fuchs, and P. Winter. 2007. Effects of periparturient systemic treatment with penethamate hydriodide on udder health and milk yield of dairy heifers. J. Dairy Res. 74:392-398.

Lundberg, A., A. Aspán, A. Nyman, H. E. Unnerstad, and K. P. Waller. 2014. Associations between bacterial genotype and outcome of bovine clinical Staphylococcus aureus mastitis. Acta Vet. Scand. 56:2.

Michel, A., C. Syring, A. Steiner, and H. U. Graber. 2011. Intramammary infections with the contagious Staphylococcus aureus genotype B in Swiss dairy cows are associated with low prevalence of coagulase-negative staphylococci and Streptococcus spp. Vet. J. 188:313-317.

Moroni, P., C. S. Rossi, G. Pisoni, V. Bronzo, B. Castiglioni, and P. J. Boettcher. 2006. Relationships between somatic cell count and intramammary infection in buffaloes. J. Dairy Sci. 89:998-1003.

National Mastitis Council. 1999. Laboratory Handbook on Bovine Mastitis. Rev. ed. National Mastitis Council Inc., Madison, WI.

National Mastitis Council. 2004. Procedures for Collecting Milk Samples in Microbiological Procedures for the Diagnosis of Bovine Udder Infection and Determination of Milk Quality. National Mastitis Council Inc., Madison, WI.

Radostits, O. M., C. G. Gay, D. C. Blood, and K. W. Hinchcliff. 2007. Mastitis. Pages 603-700 in Veterinary Medicine. A Textbook of the Diseases of Cattle, Sheep, Pigs, Goats and Horses. 10th ed. O. M. Radostits, C. G. Gay, D. C. Blood, and K. W. Hinchcliff, ed. W.B. Saunders, Philadelphia, PA.

Schällibaum, M., 1999. Mastitis pathogens isolated in Switzerland, 1987-1996. IDF Mastitis Newsletter 23. International Dairy Federation, Brussels, Belgium.

Schukken, Y. H., D. J. Wilson, F. Welcome, L. Garrison-Tikofsky, and R. N. Gonzalez. 2003. Monitoring udder health and milk quality using somatic cell counts. Vet. Res. 34:579-596.

Schwarz, D., U. S. Diesterbeck, S. König, K. Brügemann, K. Schlez, M. Zschöck, W. Wolter, and C.-P. Czerny. 2011. Flow cytometric differential cell counts in milk for the evaluation of inflammatory reactions in clinically healthy and subclinically infected bovine mammary glands. J. Dairy Sci. 94:5033-5044.

Sears, P. M., and K. K. McCarthy. 2003. Management and treatment of staphylococcal mastitis. Vet. Clin. North Am. Food Anim. Pract. 19:171-185.

Seegers, H., C. Fourichon, and F. Beaudeau. 2003. Production effects related to mastitis and mastitis economics in dairy cattle herds. Vet. Res. 34:475-491.

Sendag, S., and D. A. Dinc. 1999. Ultrasonography of the bovine udder. Turk. J. Vet. Anim. Sci. 23:545-552.

Sieber, R. L., and R. J. Farnsworth. 1984. Differential diagnosis of bovine teat lesions. Vet. Clin. North Am. Large Anim. Pract. 6:313-321.

Singh, M., and R. S. Ludri. 2001. Somatic cell counts in Murrah buffaloes (Bubalus bubalis) during different stages of lactation, parity and season. Asian-australas. J. Anim. Sci. 14:189-192.

Syring, C., R. Boss, M. Reist, M. Bodmer, J. Hummerjohann, P. Gehrig, and H. U. Graber. 2012. Bovine mastitis: The diagnostic properties of a PCR-based assay to monitor the Staph. aureus genotype B status of a herd, using bulk tank milk. J. Dairy Sci. 95:3674-3682.

Trinidad, P., S. C. Nickerson, and R. W. Adkinson. 1990. Histopathology of staphylococcal mastitis in unbred dairy heifers. J. Dairy Sci. 73:639-647.

Tripaldi, C., G. Paolacci, M. Mairelli, M. Catta, S. Orlandini, S. Amatiste, R. Di Bernardini, and G. Catillo. 2010. Effects of mastitis on buffalo milk quality. Asian-australas. J. Anim. Sci. 23:1319-1324.

Voelk, V., H. U. Graber, B. H. P. van den Borne, C. Sartori, A Steiner, M. Bodmer, and M. C. Haerdi-Landerer. 2014. A longitudinal study investigating the prevalence of Staphylococcus aureus genotype B in seasonally communal dairy herds. J. Dairy Sci. 97:4184-4192.

Zadoks, R. N., H. G. Allore, H. W. Barkema, O. C. Sampimon, G. J. Wellenberg, Y. T. Grohn, and Y. H. Schukken. 2001. Cow- and quarter-level risk factors for Streptococcus uberis and Staphylococcus aureus mastitis. J. Dairy Sci. 84:2649-2663.

Zecconi, A., E. Binda, V. Borromeo, and R. Piccinini. 2005. Relationship between some Staphylococcus aureus pathogenic factors and growth rates and somatic cell counts. J. Dairy Res. 72:203-208. 